\title{
Corporate Social Responsibility: A Case Study in Subsidiaries from Brazil and China
}

\author{
Caroline Prates ${ }^{1 *}$, Eugênio Pedrozo ${ }^{2}$, Tania Silva ${ }^{3}$
}

\begin{abstract}
Corporate Social Responsibility refers to the business' role in providing Sustainable Development through fair and appropriate relationships with its stakeholders. This study aimed to describe and analyze the CSR evolution in two subsidiaries within the same group, one located in Brazil and other in China. In general, observed similarities in CSR evolution. In both companies, the order in which the dimensions received incentives was the same, first the economic, then the environmental and lastly the social dimension. However, some differences were noted, such as the initial situation of dimensions and the time to consolidate the pillars. In Chinese company, the inicial situation about environmental and social dimension was worst. Other point refers to time toward CSR. In Brazilian' subsidiary, the CSR evolution occurredrslower. The last point refers to requirements of second order, given the non-observance of these in both subsidiaries.
\end{abstract}

Keywords: Corporate Social Responsibility; Multinational Companies; Brazil; China.

Submitted June 3rd 2015 / Approved October 7th 2015

\section{Introduction}

Despite the emergence and importance of the Sustainable Development worldwide, in some countries there are still problems that hinder the evolution of this issue, especially in emerging contexts. According to the Sustainable Development Indicators (SDI), published by the Brazilian Institute of Geography and Statistics (IBGE, 2010), socioeconomic inequalities and impacts on the environment are still widespread, which hampers the countries sustainable development. In 2012, the Global Membership Organization and Business Research of China (GMOBRC) presented a report showing that the country had experienced three decades of accelerated growth in GDP and had largely neglected environmental conservation in this period.

Conventional approaches have mainly focused on the role of governmental and non-governmental organizations in promoting infrastructure, health programs and job creation. However, recently the role of business in achieving sustainable development has come increasingly onto focus (Farias \& Farias, 2010). By adopting attitudes that positively impact society in economic, social and environmental terms, companies have an important role in sustainable development in emerging countries. In this sense, CSR appears as an alternative to the heavy social demands and limited capacity of government institutions to act in relation to these problems (Steurer, Langer, Konrad, \& Martinuzzi, 2005).

According to Frederick (1994), CSR is based on the notion that corporations have an obligation to work for the improvement of social welfare. Furthermore, in presenting an image related to socially legitimate values and principles, a corporation may be seeking to build confidence among its target publics (Vizeu \& Matites, 2013). In line to Barin-Cruz, Pedrozo and Martinet (2007) organizations, regardless of their size, should clear understand that they are facing a new global reality, where thinking environmentally and socially, without losing sight of the economic aspect is, besides being a responsible attitude, well regarded by consumers and thus results in the enhancement of the brand name. There is no need for organizations to pursue sustainability, since it will inevitably inhabit the world of work (Hopkins, 2009). However, those companies that are better structured and adapted with regard to this subject, will be ahead in the business.

Based on this, the studies that encompass Multinational corporations (MNCs), gain prominence in this context, because are in the middle of this debate, considering their huge social and environmental impact on many countries (Barin-Cruz \& Pedrozo, 2009).

Nevertheless, the paths traced by multinational corporations have been varied, especially with regards CSR in developing countries (Jamali, 2010). This debate has become quite intense in recent years, with both benefits and damages being seen to result from the internationalization process in developing countries.

Given the above, this study seeks to understand the evolution of the efforts made by internationalized companies on behalf of society, in the three pillars, economic, social and environmental, that support sustainable development. The aim is to relate CSR practices from multinational corporations located in developing countries.

In order to understand the evolution of the subject in the enterprises, a case study was conducted in a major global player, referred to as $\mathrm{X}$ group in this study, within the electronics industry and an international reference in the segment. The company, with its headquar-

1, 2, 3 Management School, Federal University of Rio Grande do Sul PPGA/EA/UFRGS, Brazil.

*Corresponding author: carol.prates@ibest.com.br. 
ters in Japan, is among the leaders of the electronics sector and has subsidiaries all over the world. Among its subsidiaries, two units are responsible for developing and manufacturing of the same products, one located in China and the other in Brazil. The experience of these subsidiaries in relation to the issue and their contextualization lead them to compose the object of analysis of this research. In this case study was possible to find differences and similarities between two subsidiaries towards CSR.

A contribution of this research have been obtained at the theoretical level, given that it examines CSR in an emergent context. Still it is important to note that these studies, with Steurer et al. (2005) approach, were almost conducted in Europe, there are few empirical studies in Brazil and China. Moreover, other important contribution refers to the use of path dependence aslanalyticalestructure for historical researches.

In addition to this introduction, this paper is divided into five more sections. The second section refers to two theoretical approaches necessary to conduct the research. The third section describes the methodology used. The fourth section provides a characterization about object of analysis and presents the results and discussions of this paper. After which, some final thoughts are expressed regarding this research.

\section{Corporate Social Responsibility in Developing Countries}

This chapter introduces the theoretical approaches used in this research. The first section presents the main approaches about CSR and its development in Brazil and China. In order to analyze the evolution of these events, the Path Dependence phenomenon is discussed in the second section.

\subsection{From sustainable development to corporate social responsibility}

According to the World Commission on Environment and Development, sustainable development is understood as one that meets the needs of the present without compromising the ability of future generations to meet their own needs (WCED, 1987). Since sustainable development was first conceptualized, one of the divergent points among the currents of thought refers to its scope. The vast majority of scholars accept the three classical environmental, social and economic dimensions, which are considered to make up the triple bottom line (Elkington, 2004). Regarding these dimensions there is debate about their relative priorities and how they should relate to each other in view of the integration, communication, exchanges and synergy between the goals of the dimensions (Munasinghe, 2007).

Considering the area under study, the incorporation of the principles of sustainability into business practices has emerged as a prominent theme in both the academic and professional fields, since besides demonstrating an awareness of the role of business in society, it can also be seen as a differential within the market. Sustainable management has allowed corporations to implement strategies that encompass concerns of great importance to society on a local, regional or global level (Gray \& Milne, 2002).
As Sustainable Development, the concept of CSR coupled with the relationship with internal and external stakeholders, is older than it looks, but became popular only after 1980 (Steurer et al., 2005). Contrary to neoclassical economists who saw firms as closed systems, only geared to its shareholders, after the mid-1980s, the business-society relations pave the corporate environment for its societal context (Dill, 1958). In 1984, Freeman's book Strategic Management: A Stakeholder approach, stabilized the CSR as a popular research field through the use of strategic relationships with key business partners in order to promote a win-win game, that is, the broker sustainability through this good relationship with stakeholders, the company acquires competitive advantage.

CSR, in turn, emerges in the academic context, in the 1950s. However, the diversity of definitions shows that there is no agreement on how the issue should be defined (Carrol \& Shabana, 2010). Hopkins (2005) describes that in the literature there is no consensus on the question of whether CSR should be conceptualized as a purely voluntary approach or how it should be strictly regulated, forcing companies to suit up. While there are these distinctions, this is the usual definition and more adopted by the academic community.

In last decades, CSR has progressively moved from ideology to reality and literature management has significantly contributed to the definition and characterization of the phenomenon as well as for the development of discussions on best practices and their impact on the reputation and financial performance (Maon, Lindgren \& Swaen, 2010). This change was also accompanied by an evolution of the concept of CSR, beyond the purely pragmatic and focused on the financial return to a more holistic and integrative perspective.

The theme has grown into distinct research lines with different epistemological positions (Gond \& Matten, 2007). One line which has gained notoriety due to its dynamism and practical orientation relates to the business environment in order to investigate the processes that involve the application and integration of CSR activities and organizational structures (Maon \& Swaen, 2009).

Maon and Swaen (2009) argue that for some corporations, the pressures to adopt responsible behavior have demanded real and important changes in their daily activities, culture and organizational structures in order to make CSR a core activity in the organization.

In this context is important related CSR with the main stakeholders. Steurer is one author who has discussed this subject in recent years, emphasizing the management of relationships with key stakeholders. The study by Steurer et al. (2005) proposed a framework that, in addition to the traditionally known dimensions (economic, social and environmental) included also a fourth dimension (the second-order requirements), which emphasizes transparency, participation, reflexivity, integration and intergeneration, particularly in view of the stakeholders.

The authors proposed fourteen points which were subdivided into the four dimensions (Table 1). This proposal can be used to map organiza- 
tions activities and classify them according to their development, in view of the stage they are at (Societal, Corporate Management, and Systems) and their relationship with stakeholders. Additionally, one can see which dimensions dominate (Economic, Social, Environmental and Second Order). Importantly, the Second Order suggested by Steurer et al. (2005), concerns the connections and interactions between all dimensions.

\begin{tabular}{|l|l|l|}
\hline Dimensions & Concerns & Aspects \\
\hline Economic responsibility & $\begin{array}{l}\text { To perform in a way that enables the company to con- } \\
\text { tinue for an indefinite time }\end{array}$ & $\begin{array}{l}\text { Financial performance; } \\
\text { Long-term perspective; } \\
\text { Economic impact. }\end{array}$ \\
\hline Social responsibility & $\begin{array}{l}\text { To contribute to the social well-being of the society and } \\
\text { individuals }\end{array}$ & $\begin{array}{l}\text { Equity within a corporation; } \\
\text { International equity; } \\
\text { Internal social improvements; } \\
\text { External social improvements. }\end{array}$ \\
\hline Environmental responsibility & $\begin{array}{l}\text { To maintain natural capital to a certain (i.e. para- } \\
\text { digm-specific) degree }\end{array}$ & $\begin{array}{l}\text { Resources; } \\
\text { Emissions; } \\
\text { Environmental damages and risks. }\end{array}$ \\
\hline Second-order requirements & $\begin{array}{l}\text { SD has to follow some superior process and concept } \\
\text { requirements when it addresses the three dimensions }\end{array}$ & $\begin{array}{l}\text { Transparency and participation; } \\
\text { Reflexivity; } \\
\text { Integration of dimensions I-III; } \\
\text { Intergenerational equity. }\end{array}$ \\
\hline
\end{tabular}

Table 1. Operationalization of corporate responsibility. Source: Adapted from Steurer and Konrad (2009).

This framework, although it was created seven years ago, is used in current empirical studies, as seen in the research by Konrad, Steurer, Langer, and Martinuzzi, (2006); Steurer and Konrad (2009); and Málovics, Kano and Imreh (2011). However, it is important to note that these studies were all conducted in Europe. To the best of our knowledge, there few empirical studies that specifically employ this framework in Brazil and in China. Similarly, there are no theoretical studies that use this approach in relation to the CSR evolution.

\subsubsection{Corporate social responsibility in Brazil}

Brazil was characterized throughout its history, by building of a society marked to a high degree of socioeconomic inequality, since millions of Brazilians didn't have rights to benefits achieved during the development process (Abreu, Castro, Soares, \& Da Silva Filho, 2012). During the last two decades of the twentieth century were witnessed actions of society in order to reduce the social and economic contrasts between population and boost the country towards greater social justice (Parente, 2004), however, indicators of sustainable development the country still have a great social and economic inequality (IBGE, 2010).

The history of CSR in the Brazilian private sector date from 1961, since the creation of the Christian Business Leaders Association (CBLA) and the appearance of Law 76.900/75, which required companies to provide individual information about yours employees. Another important factor that expanded the discussion of the theme was the emergence of the Social Balance. It is in 1984 that the Nitrofértil Company, located in Bahia state, publishes what is considered the first Brazilian Social Balance. In the same period, was being held in the social balance of Telebrás Company, published in mid-1980.
The Banespa Company, conducted in 1992, forms the list of precursor companies in Brazil that published their Social Balance.

According to Torres (2001), the main function of the balance sheet of the company is to make public the company's social responsibility. This is part of the process of transparency for the general public, to consumers and to shareholders and investors about what the company is doing in the social area.

With the emergence of several non-governmental organizations and the development of the third sector in Brazil, the movement intensified in the 1990s. Institutions as the Ethos social responsibility and Information Network of the Third Sector (INTS) were created in order to highlight the importance of social actions for business and society, leading to the discussion of new terms as corporate philanthropy, corporate citizenship, business ethics, corporate volunteering and social responsibility in corporate environments (Tenório \& Nascimento, 2006).

The growing search for a socially responsible behavior by companies in Brazil had their bases in different motivations. At the same time as consumers become more aware, the information flow to market faster and can tarnish the reputation of a company quickly. Moreover, companies are beginning to glimpse also opportunities. In general, Brazilian companies looking to achieve with the implementation of the CSR meeting the needs and interests of its stakeholders and the preservation and improvement of enterprises, gaining a greater number of customers, hiring employees motivated and achieving better financial returns (Santos, 2009). These goals reinforce the construction companies that do not simply paying taxes and compliments the laws, but that work on developing a fairer society, acting in a socially 
responsible and transparent manner (Parente, 2004), contributing to more broadly, with the country's sustainable development.

\subsubsection{Corporate social responsibility in China}

The movement of CSR in China was highlighted from the mid-1990s (Myllyvainio \& Virkkala, 2006; Zhou, 2006; Abreu et al., 2012). Multinationals have brought CSR from Western to the Chinese market during the anti-sweatshop campaign that built an opposition to the unacceptable conditions in the supply chain in developing countries (Pun, 2003).

The need for integration of CSR in China has been driven by international pressures motivated by the lack of concern about the health, safety, excessive working hours and adoption of labor laws below international standards which consequently resulted in the launch codes conducts business in relation to labor standards in China (Pun, 2003). Chinese companies only started to passively accept these rules, regulations and codes of conduct on working conditions, labor rights, labor conditions, health and safety because their buyers forced them to do so (Zhou, 2006). The relationship with the rest of the world became more narrow and intense and consequently China has become more dependent on other countries due to numerous commercial and political securities (Myllyvainio \& Virkkala, 2006).

Another factor that raised discussions about Chinese social conditions was the increase in outsourcing of production from Western countries to China, due to low salaries paid by enterprises (Buhmann, 2005). Myllyvainio and Virkkala (2006) point out that China is one of the economies with greater supply of manpower, due to excess over 150 million people located only in rural areas.

From 1995 to 1998, only a few large multinationals and some large Chinese companies were looking for the implementation of codes of conduct, and only after the year 1998, a greater number of multinational companies began to apply those (Abreu et al, 2012). Before 2001, the CSR was limited to the interior of the factories with accompanying audits. Consumers, government and the media were not aware of CSR at that time. Even workers in factories that were present during audits knew the theme marginally (Pun, 2003).

According Myllyvainio and Virkkala (2006) the year 2005 was designated as the period of CSR in the Chinese media, where events were organized aiming at building a harmonious society where there was a CSR within Chinese enterprises, having as ultimate goal draw more attention to social justice and solve problems for the common people, improving the quality of life. Economic growth was still a key point, but greater emphasis should be directed to the interests of the majority of the population (Myllyvainio \& Virkkala, 2006).
In general, the CSR in China can be seen as an action to make Chinese companies more competitive in the global marketplace, and protect and enhance their brands, able to compete with major global competitors, addressing issues important to its employees, customers, investors and stakeholders and becoming long-term, sustainable (Levine, 2008). Was prompted by international pressure and followed the model proposed in the West, which created guidelines and standards such as SA 8000 and ISO standards. The few local Chinese standards as CS9000T are recent. China is becoming a major player in CSR, but their practices and concepts are still recent (Wang \& Juslin, 2009).

\subsection{Path Dependence}

The quest to understand what has motivated the development of initiatives related to sustainability as well as the trajectory of these events requires an understanding of the historical facts, which, in this study, will be addressed by means of the phenomenon Path Dependence.

The term path dependence is used in the sense that all processes are dependent on the decisions taken in the past, which are each step had feedback of the others steps in the organizational trajectory, so that, the choices available in the present are the result of the choices made in the past.

According to Hoff (2011), although the idea of path dependence is generally be used in studies of technological spread or change, it has been increasingly common to find it applied in studies of Humanities and Social Sciences, where it is used in order to understand processes of change in societies. Moreover, some authors indicate that the available technology is always a limiting factor for the adoption of more environmental friendly postures (Shrivastava, 1995; OECD, 2001). The choice of technologies, combined with the study of historical developments, suggest that some settings within an observed system arise from the trajectory that the system adopted (Hoff, 2011).

As a result, Hoff (2011), based on search of the literature, discussed previously studied elements within the concepts of path dependence, as well as the methods used for this type of study, and added to these elements from historical research, in an attempt to developing an analytical framework for the application of path dependence. The analytical framework built by the author can be seen in Figure 1.

For building the analytical framework, the author used contributions from Evolutionary Theory, through the studies of Nelson and Winter (1982) and other authors as Goldstone (1998), and Hansen (2002).

Hoff (2011) identifies five different moments that should be considered in historical research: (i) antecedent conditions, (ii) Critical conjuncture, (iii) Structural persistence, (iv) Reactive sequence, and (v) Results. 


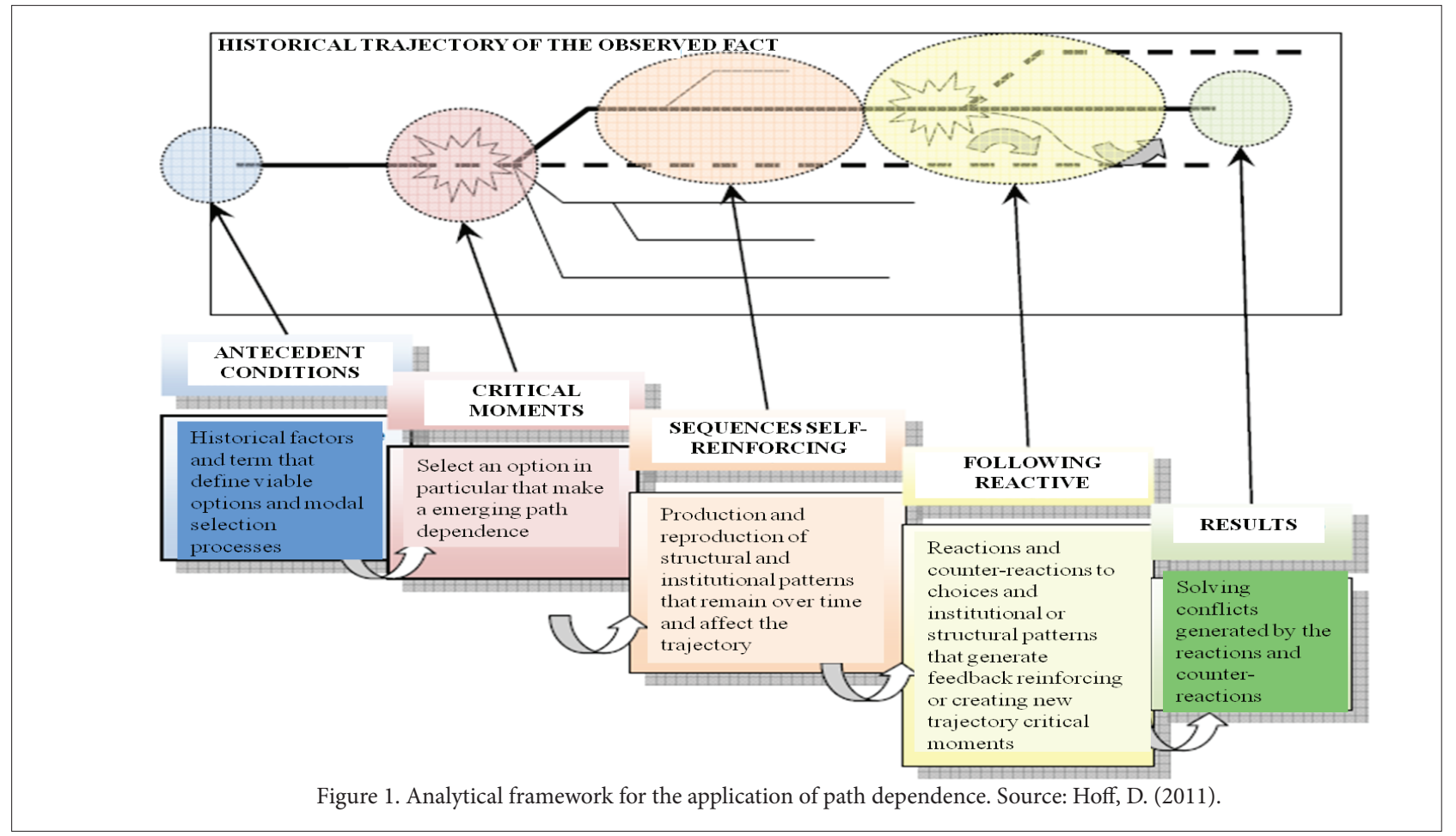

Finally, it should be emphasized that the analytical framework proposed by Hoff (2011) will be used in the analysis of events related to the evolution of the CSR.

\section{Research Procedures}

The research is characterized as a qualitative case study, because it is an empirical investigation that reflects the reality of a unit of study, in this case, the fictitiously named group X (Yin, 2011). Given the objectives outlined in this study, it was necessary for the object of the study to be appropriate to the issue involved, so that it had to be a group that was internationalized, and had subsidiaries in Emergent countries. Based on these assumptions and considering the global prominence, group $\mathrm{X}$ was chosen, with the Brazilian and Chinese subsidiaries being objects of analysis in this study. Moreover, the subsidiaries in question are apt for comparison, given their similarities in terms of organizational structure and the mix of products developed and manufactured in the plants.

With respect to the collection of information, data were extracted by conducting semi-structured interviews and observation by the author. Interviews were held with ten employees, five from each subsidiary, who had experienced these changes. Information about interviewed is present in Table 2. The interviews were conducted from October 2012 until july 2014, lasted seventy-five minutes each on average.

\begin{tabular}{cccc}
\hline Interviewed & Role & Time in the X Group & Subsidiarie \\
\hline A & Operation Director & 35 & Brazil \\
\hline B & Operation Manager & 33 & Brazil \\
\hline C & Quality Analist & 18 & Brazil \\
\hline D & Product Engineer & 18 & Brazil \\
\hline E & Process Engineer & 22 & Brazil \\
\hline F & Engineer Manager & 30 & China \\
\hline G & Operation Manager & 15 & China \\
\hline H & Quality Analist & 8 & China \\
\hline I & Product Engineer & 10 & China \\
\hline J & Process Engineer & 11 & China \\
\hline
\end{tabular}

Table 2. Information about Interviewed 
The observation by the author with focus in the subject was performed for seven months in Brazil (january-july, 2012) and for ten days in China (July, 2014). One of the authors worked in the Brazil company, because of this was possible to study these plant for more time. The same author visited the Chinese plant for 10 days to observe these points and conclude the interwiews.

In addition to the primary data, the study used secondary data sources obtained by means of documentary observation in reports, company websites and other publications from the organization, as well as by consulting specialized media about the electronics industry. About the reports was analized indicators about enviromental and economic management, human resources, water control and risk management. Data analysis was performed in the light of the above-mentioned theoretical references. The historical approach was taken in an attempt to understand the evolution of CSR for which Hoff (2011) path dependency' analytical framework was used. The analytical categories and subcategories were predetermined based on the theoretical references (Steurer et al., 2005).

\section{Analysis}

\subsection{The Case}

The X Group, operating in the electronics industry, is present in about 40 locations with more than 50 plants installed. Among these plants, the Brazilian and Chinese subsidiary were studied.

\subsubsection{The Brazilian subsidiary}

The Brazilian subsidiary develops and manufactures capacitors. In the market, it is differentiated due to the quality of its products, not their price. It was founded in 1954 by the descendants of German immigrants in the state of Rio Grande do Sul. Its foundation was motivated by the growth of the electronics industry, mainly focused on manufacturing radios. The constitution of the company represent the first critical moment of change. During this time, the only concern of the company was survive in the market, focusing in the economic improvements. Its founders did not control the efficiency of their processes and material consumption well as potential impacts that could be caused to the environment.

In Brazil, at that time, the prevailing economic model was the so-called, 'developmentalism', in which Brazil developed much of its infrastructure in a short time and achieved high rates of economic growth. However, the Governments accounts were often out of balance, the foreign debt multiplied and triggered a massive inflationary wave.

Due to the economic difficulties of the period, in 1957, the company was fully acquired by a multinational group, which marks the second critical moment of change. At the same time, the company began to supply not only the domestic market but also export, although on a small scale. In 1962, seeking to extend the business, its manufacturing facilities were transferred to the metropolitan area of Porto Alegre. That same year the product mix offered to the market began to be expanded.
Between 1969 and 1973, Brazil experienced the so-called Economic Miracle, when the rapid growth of the industry created jobs and raised the income of many workers. In this same period, the company increased its sales in the domestic market and worked to improve the quality of its products and processes in order to reduce the amount of labor required to manufacture of capacitors. About $5 \%$ of its production was being sent to foreign markets, mostly in Europe. The controls in the factory was only about production quantity. The quality was inspected in the final of the process, after the product has already been finalized. Didn't have a concern about number of scrap or material consumption.

During the 1990s, the main theme of Fernando Collor's Government was the failure of 'developmentalist' project as an engine for growth. From then on, there was growing trade liberalization and a series of privatizations. Several largely inefficient companies, especially in the computer industry, went bankrupt while the quality of products improved substantially.

During this period, the company needed to restructure its production technology and considerably reduced the number of employees in order to adapt to changing market demands and become more competitive. In addition, it directed efforts achieve greater quality and efficiency, acquiring, initially, the ISO 9000. In 1992, the company gained recognition within the group as a center of competence, and autonomy, as well as for producing, developing and negotiating new products without prior authorization from the headquarters. This fact corresponds to the third critical moment of change that occurred in the company. During this period, the company consolidated the economic pillar. By preparing for the foreign market before the opening of the markets in Brazilian it passed through the crisis more easily than other companies of similar size and so conquered its 'independence. With improvements in the process, it was possible to perform quality inspections during the process, reducing the scraps quantity. In addition, the company, in this period, began to manage their waste and take care of their disposal. Reduction of scraps controls were included in the process.

In Brazil, monetary stability was only achieved with the implementation of the Real Plan in 1994. As a consequence of the end of high inflation, there has been an unprecedented improvement in terms of income for the lower classes. In the last decade, the company has come to export $70 \%$ of its products.

Later, in 1999, the company became part of another group, which grew out of the merger of two corporations and opened its capital on the stock market. The fourth critical moment of change occurred in 2002, with the change of name due to the earlier merger. Since then, the company introduced a series of changes and gained certifications: in 2003 it was certified ISO TS 16949, a prerequisite for supplying the automotive market; in 2004, it received ISO 14001 (environmental management); in 2005 it was awarded Outstanding Company "Sustainable RS"; and in 2008, it adopted the lean manufacturing system, striving for even more efficiency. It by obtaining the ISO 14001 certification, by disposal and scrap control its environmental dimension 
has been consolidated. It is important to emphasize that a firm was more efficient because of the lean manufacturing system and its help the environmental dimension cause there are less material and resources consumption.

In 2009, the company underwent another merger, creating the above-mentioned group X. At this same time, at the height of the global crisis, the company withdrew some benefits that had been granted to employees, which culminated in rising turnover and absenteeism. In 2012, after a strike by employees, the fifth and final critical moment of change occurs, in which the main representatives of the company began to rethink some attitudes, some going back on earlier decisions and giving greater emphasis to the social pillar.

A brief list of critical moments of change, and their respective consequences on the dimensions from Brazilian Subsidiary is given in Table 3.

Table 3. Critical Moments of change in Brazilian Subsidiary

\begin{tabular}{|l|l|}
\hline \multicolumn{1}{c|}{ CRITICAL MOMENTS OF CHANGE } & \multicolumn{1}{c}{ IMPACT ON THE DIMENSIONS } \\
\hline 1954 - Company founded & - Economic difficulties \\
\hline 1957 - Company acquired by a multinational & $\begin{array}{l}\text { - Impulse to economic issues as a result of expansion } \\
\text { of the product portfolio and starting exporting } \\
\text { - Impacts on environmental issues }\end{array}$ \\
\hline 1992 - Recognition of the company as a Center of Competence & $\begin{array}{l}\text { - Consolidation of the economic pillar } \\
\text { - Efforts begin to consolidate the environmental pillar } \\
\text { - Growth of exports }\end{array}$ \\
\hline 2002 - Merger and the formation of a new group & - Consolidation of the environmental dimension \\
\hline 2012 - New view of the social dimension & - Improvements to the social dimension \\
\hline
\end{tabular}

Currently, the company develops and manufactures plastic film capacitors, power capacitors and aluminum electrolytic capacitors, and even processes aluminum foil and plastic film for its own use. It currently has 1770 employees, producing approximately 2 billion components a year, which are supplied to nearly 250 clients worldwide. Nearly $70 \%$ of the components produced at the factory are intended for export to Europe, Asia, NAFTA (North American Free Trade Agreement) and Central and South America.

\subsubsection{The Chinese subsidiary}

This subsidiary is one of the group's plants located in China. Specifically, it is the plant located in Xiamen which develops and produces electrolical capacitors. In the market, it stands out due to the quality and cost of its products.

The company was incorporated in 1994, which constitutes the first critical moment of change. The economic period and the entertainment industry, which was expanding at the time, were the main drivers for the creation of the company. This company, like much of Chinese industry, was favored by the country's economic reform in the late 1970s and due to this fact and the company's strategic objectives, it already offers part of its production to foreign markets, with large bias only towards the economic pillar. Regarding social issues, the conditions were very poor. As most of the workers live in remote areas, companies usually offer accommodation where employees can spend the week. The infrastructure offered for the company was very poor, with overcrowded dormitories, lack of ventilation and no recreational areas, among others. In the factory, was very hot (about $50^{\circ} \mathrm{C}$ ) and with high number of work accidents. In the environmental area, the conditions was very deprived too, with high consumption of energy and resources, problems with product quality and high number of scrap in the production.

In the period 1978-1992, investments are mainly focused on light industry. This approach favored energy efficiency in the country, since this type of project demands less energy, and also with manufacturing a greater number of jobs were provided for the urban workforce that had migrated from rural areas.

The economic focus on light industry led the Chinese subsidiary to expand its segmentation and include the automotive industry in its sales portfolio. This demanded an improvement to the quality system which resulted in ISO TS 16949 certification, a prerequisite for supply to the automotive market, in 2003. Until then, the company had not shown any concern about environmental resources and increasingly sacrificed the social pillar in favor of the economic pillar. With exposure to the automotive market, the company had to concern itself a little more with efficiency and so began to exert greater control on the environmental dimension, like water and energy control and scraps reducing. The impact on the social pillar remained negative.

As a result of the onset of rapid economic growth in China and the expansion of the company's portfolio, in 2004 a multinational group interested in the performance of the passive components business, while viewing the asymmetry with its own business, proposed a merger.

Like the Chinese subsidiary, many other foreign enterprises opted to invest in China. As a consequence, there was a considerable increase in exports, especially of manufactured products, strengthening the creation of the Chinese industrial complex. China then began to 
aggregate the production chain as a whole, attracting more diverse enterprises.

Due to both the expansion of the Chinese industrial complex and the merger, the company began to change in its segmentation, reducing its share of the entertainment market and increasing that of industrial market. Importantly, the company is an intermediary in the chain and the expansion in several areas (automotive, telecommunications, energy, etc.) within the Chinese market, motivated this change in segmentation.

This shift in segmentation, in turn, led to in several changes within the company. As the industrial market is more demanding than the entertainment market, not only on issues related to quality, but also in terms of the legal requirements aimed at addressing environmental and social dimensions, the company had to adapt. Furthermore, there was already a need for the company to improve in some areas in order for it to match other subsidiaries within the group. As a result, the company modernized its machinery, making the production system more efficient, implemented the ISO 14001 environmental management in 2004 and started the water and energy control. This improvements and the implementation of ISO 14001 marks the consolidation of the environmental pillar in the company. Because of this moment importance and its impact in the company culture, this event corresponds to the second critical moment of change.

Concern ISO 14001, it is worth noting that the company did not have to make many changes, given that since obtaining the ISO TS 16949 , it was already concerned with such issues, so much so that, soon after the merger, the company was awarded the certificate. The company was not certified, but had the main requirements for obtaining certification, the new group had only to improve some aspects and create control systems in order to effectively achieve certification.

Regarding social issues, the conditions were very poor before the merger. As most of the workers live in remote areas, companies usually offer accommodation where employees can spend the week. The infrastructure offered was very poor, with overcrowded dormitories, lack of ventilation and insufficient recreational areas, among others. With the merger, the company began to enlarge the dormitories, reduce the number of users per room, install suitable ventilation and build recreational areas. In addition, there was a greater concern for safety and hygiene in the work area. As a result, the company achieved the OHSAS 18001 - Security Management and Hygiene at work certificate - in 2007, representing the company's third and final critical moment of change and further strengthening its social pillar. Nowadays, the dormitories are very cleaning, have Wi-Fi signal, stay in front of alimentation place of the company and it is possible some parents live with workers in dormitories. This service (food and dormitories) are good and free for worker and their family.

In 2009 another merger occurred, in which the previously mentioned group X was established. A brief list of critical moments of change and their respective consequences on the dimensions from Chinese Subsidiary is given in Table 4 .

\begin{tabular}{l|l}
\multicolumn{1}{c|}{ CRITICAL MOMENTS OF CHANGE } & \multicolumn{1}{c}{ IMPACT ON THE DIMENSIONS } \\
\hline 1994 - Company founded & $\begin{array}{l}\text { - Consolidation of the economic pillar } \\
\text { - Negative impacts on the environmental and social dimensions }\end{array}$ \\
\hline 2004 - Merger and the formation of a new group & $\begin{array}{l}\text { - Consolidation of the environmental dimension } \\
\text { - Beginning of social improvements }\end{array}$ \\
\hline 2007 - Awarded social certificate & - Significant improvement to the social dimension \\
\hline
\end{tabular}

Table 4. Critical moments of change in Chinese Subsidiary

Currently, the company has about 480 employees, producing approximately 3.8 million components per year, $90 \%$ of which are supplied to the domestic market. While the company also exports to Japan, Brazil and Europe, its efforts are directed at supplying the domestic market with quality products, but at the same time low cost. It is important to note that the company, being in an intermediate position in the chain and having the Chinese market as the main end producer in this segment, focuses on domestic sales.

\subsection{The Evolution of Corporate Social Responsibility}

There are, in general, similarities in the evolution of CSR in the studied cases. In both companies, the order in which the dimensions received incentives was the same, first the economic, then the environmental and lastly the social dimension. However, some differences were noted, such as the initial situation of some dimensions and the faster consolidation of the pillars in the group X. A brief illustration about critical moments of change and their respective consequences on the dimensions is given in Figure 2.

The Brazilian company took over 25 years to strengthen its economic dimension. Consolidation was only achieved in 1992, with the third critical moment of change, when the company was recognized as a center of competence by the group.

The environmental dimension also entered the agendas of the two 
companies at different times. Although in view of the difference between the two companies in terms of length of time in the market, the consolidation of this pillar occurred almost simultaneously. The Brazilian company has to show concern about the environmental dimension as from 1992, with the expansion of markets, while in the Chinese company this began in 2003, when it included the automotive segment in its business portfolio. However, it is only after the mergers, occurred in 2004, that consolidation effectively happens, structuring environmental issues and creating a management process that allowed the acquisition of the ISO 14001 for both companies. At this point, it is important to note that the Brazilian company became part of a new group in 2002, marking the company's fourth critical moment of change, while the Chinese com-pany became a member of the same in group in 2004, design the second critical moment of change in this company, according to path dependence approach (Hoff, 2011). This fact highlights the importance of organiza-tional culture in the studied cases, influenced primarily by the strategic issues of the group in its subsidiaries.

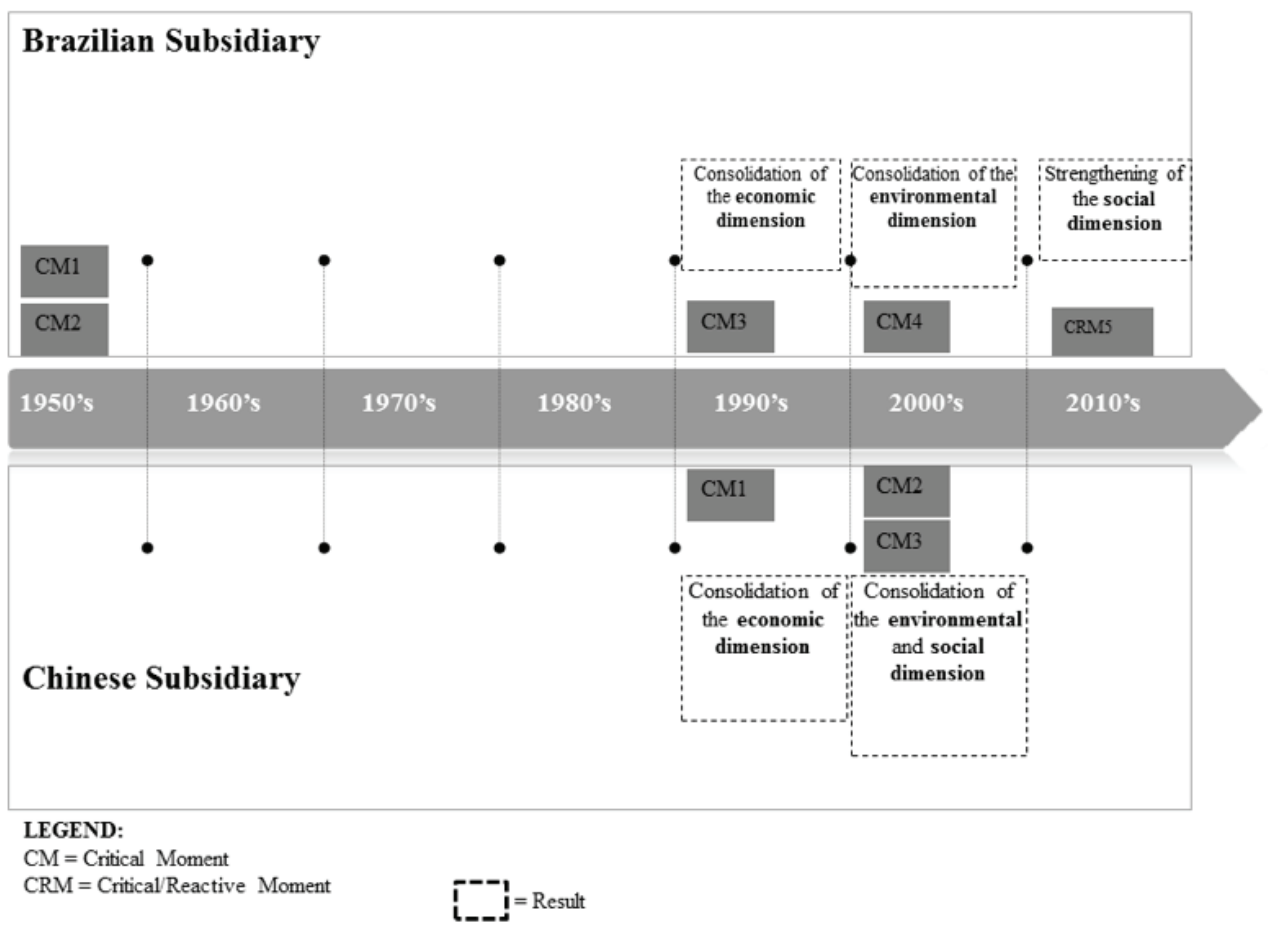

Figure 2. CSR Evolution in the Subsidiaries

The social dimension was balanced in the Brazilian company until the height of the global crisis (2008-2009). Until then, the company had always focused on maintaining attractive employee benefits and pro-viding very favorable physical and psychological working conditions. However, with the crisis, in order to keep the economic dimension stable, the company cut some benefits and reduced the quality of the health plan. These changes led to increased employee turnover and absenteeism, as a result of which the company's hiring and training costs rose, while there were also problems with the reduced produc-tivity and quality due to the relatively less experienced workgroup. Moreover, in early 2012, following the publication of the results and equity participation for 2011, the withdrawal of the benefits led to strike by more than $70 \%$ of the workforce in the company.

This stoppage represented a reactive sequence, according to Hoff (2011), which produced a new critical moment of change, when the company started to reconsider its concepts concerning the social di-mension and the consequences, both financial and in terms of the company image in the eyes of its clients and society, of its non-com-pliance on this issue. It is important to point out that failure to comply with the second order requirements recommended by Steurer et al. (2005) meant that, in that period, the company experienced losses in terms of quality and costs in general, causing it to regress on an issue that had hitherto been balanced.

In the Chinese company, the social issue had been largely neglected for 10 years. Since its establishment in 1994 until the merger in 2004, the company had sacrificed this dimension in favor of the economic one. The company made cuts in the social dimension, which was already precarious, in order to reduce costs and promote greater profitability. In 2004, this aspect came to be widely challenged, in view of the new direction outlined as a result of the merger. After a series of 
improvements in working conditions and also in the dormitories and living areas, in 2007, the Chinese company obtained OHSAS 18001 certification, which highlights the control and management of social aspects, health and safety at work. This certification has not been obtained by all the group's subsidiaries - the Brazilian subsidiary has not been awarded this certificate, but it is the group aims to make it common in all its plants.

In both the Chinese and Brazilian cases, it is important to point out that the failure to comply with the fourth dimension, proposed by Steurer et al. (2005) as second-order requirements, meant that many aspects first had to be discredited before subsequently being improved. In the Chinese company, the same occurred to some degree with the environmental issue, which, during the economic growth phase only received attention after the misuse of funds was shown by the external market and, directly, in the social issue, given that the conditions for workers were sacrificed in order to maintain economic sustainability. In the Brazilian company, failure to comply with the fourth dimension was apparent in the period 2008 to 2009, at the height of the global crisis, in which social issues were negatively affected in order to maintain the economic dimension stable.

In short, it is possible to observe Chinese subsidiary toward CSR faster than Brazilian company. The initial condition in Chinese company were worst, but the changes occurred quickly while in Brazilian, the initial conditions were better, but the reaction was more slowly. This difference could be caused cause the year 2005 was designated as the period of CSR in the Chinese media, where events were organized aiming at building a harmonious society where there was a CSR within Chinese enterprises according Myllyvainio and Virkkala (2006).

In the contexts of the companies, there is a need for greater awareness regarding the second order requirements (Steurer et al., 2005), since they are intended to provide a greater balance between the dimensions. Probably, with the immersion of this fourth dimension within the organizational culture, a more linear evolution of CSR may be possible.

\section{Final Remarks}

CSR is a term that refers to the role of business in providing sustainable development by maintaining a fair and appropriate relationship with its various stakeholders. It is particularly relevant today given the limited possibility of government organizations meeting all social needs, especially in developing countries. In an effort to investigate the topic in greater depth, this study has sought to describe and analyze the evolution of CSR in companies located in developing countries. Therefore, a study was conducted in two subsidiaries of the group $\mathrm{X}$, one located in Brazil and the other in China.

There are, in general, similarities in the evolution of CSR in the studied cases. In both companies, the order in which the dimensions received incentives was the same, first the economic, then the environmental and lastly the social dimension. However, some differences were noted, such as the initial situation of some dimensions and the time to consolidate the pillars.
In Chinese company, the initial situation about environmental and social dimension was worse than Brazilian company. For economic dimension this situation was different, the Chinese subsidiary had more conditions than Brazilian subsidiary because of the economic context and government approach.

Other point refers to time toward CSR. In Chinese' subsidiary, the CSR evolution occurred faster than Brazilian' Subsidiary. While Brazilian Company needed more than 50 years to promote CRS the Chinese' Subsidiary required about 12 years to do this. Both Chinese Culture and the Political Context could be to influence this result. However the intensification of sustainable development in recent years and the creation of the Chinese subsidiary in the same period should be primarily responsible for this result faster.

Finally, results pointed that both Chinese and Brazilian companies didn't observe the second-order requirements during the way toward CSR.

This study has contributed towards the analysis of CSR in companies located in developing countries. Others important contributions refers to the use of path dependence as analytical structure for historical researches and application of Steurer approach in emergent contexts.

For future researches, further studies including comparison with the holding company are suggested so that more specific details can be brought to light. Into recently formed younger companies, arising from other contexts, may provide different results and so enrich this discussion. Finally, another approach that was quite prominent in this study and deserves further study concerns the second-order requirements. These requirements, identified as the fourth dimension, were shown to be crucial for achieving a more homogeneous evolution of CSR in the companies. Research into these requirements within companies, as well as ways to operationalize the subject in the organizational environment, could help to bring about CSR more fully and faster.

\section{References}

Abreu, M., Castro, F., Soares, F., \& Da Silva Filho, J. (2012). A Comparative Understanding of Corporate Social Responsibility of Textile Firms In Brazil And China. Journal of Cleaner Production, (20), 119126. http://dx.doi:10.1016/j.jclepro.2011.08.010

Anderson, E., \& Gatignon, H. (1986). Modes of foreign entry: a transaction cost analysis and propositions. Journal of International Business Studies, 17(3), 1-26. http://dx.doi.org/10.1057/palgrave.jibs.8490432

Barin-Cruz, L., Pedrozo, E., \& Martinet, A. (2007). Estratégias de Desenvolvimento Sustentável em grupos multinacionais: o estudo de dois casos franceses no setor do varejo. Revista de Gestão Social e Ambiental, (3), 58-78. http://dx.doi.org/10.5773/rgsa.v1i3.32

Barin-Cruz, L., \& Pedrozo, E. (2009). Corporate social responsibility and green management- Relation between headquarters and subsidiary in multinational corporations. Management Decision, 47(7), 1174-1199. http://dx.doi.org/10.1108/00251740910978368 
Buhmann, K. (2005). Corporate social responsibility in China: current issues and their relevance for implementation of law. The Copenhagen Journal of Asian Studies, v. 22.

Carroll, A., \& Shabana, K. (2010). The Business Case for Corporate Social Responsibility: A Review of Concepts, Research and Practice. International Journal of Management Reviews, 12(1), 85-105. http:// dx.doi.org/10.1111/j.1468-2370.2009.00275.x

Dill, W. (1958). Environment as an Influence on Managerial Autonomy. Administrative Science Quartely, 2, 409-443. http://dx.doi. org/10.2307/2390794

Elkington, J. (2004). Enter the triple bottom line. In: Henriques, A.; Richardson, J. (Ed.). The triple bottom line: does it all add up. London: EarthScan. http://dx.doi.org/10.4324/9781849773348

Farias, C., \& Farias, G. (2010). Cycles of poverty and consumption: the sustainability dilemma. Competitiveness Review: An International Business Journal, 20, 248-257. http://dx.doi. org/10.1108/10595421011047433

Frederick, W. (1994). From CSR1 to CSR2. Business and Society. 33 (2), 150-164. http://dx.doi.org/10.1177/000765039403300202

Garrido, I. (2007). A Relação entre Orientação para o Mercado Exterior, Estratégias de Internacionalização e Performance Exportadora (Doctoral dissertation). Federal University of Rio Grande do Sul, Porto Alegre, Rio Grande do Sul, Brazil. Retrieved April 10, 2012, from http://www.lume.ufrgs.br/handle/10183/8849.

GMOBRC - Global Membership Organization and Business Research of China. (2012). Business and Sustainability in China: Company Responses to a National Priority. Retrieved July, 15, 2012 from http://www.prnewswire. com/news-releases/sustainability-in-china-report-details-how-companies-are-responding-to-a-national-priority-135166818.html.

Goldstone, J. (1998). Initial conditions, general laws, path dependence, and explanation in historical sociology. American Journal of Sociology, 104, p. 829. http://dx.doi.org/10.1086/210088

Gond, J., \& Matten, D. (2007). Rethinking the business-society interface: beyond the functionalist gap. ICCSR Research Paper Series, Nottingham University Business School, 47.

Gray, R., \& Milne, M. (2002). Sustainability reporting: Who's kidding whom? Chartered Accountants Journal of New Zealand, 81, 66-70.

Hansen, R. (2002). Globalization, embedded realism, and path dependence: the other immigrants do Europe. Comparative Political Studies, 35, 259-283. http://dx.doi.org/10.1177/0010414002035003001

Hoff, D. (2011). A história importa: proposta de estrutura analítica para o estudo de path-dependence. Ensaios FEE, 32 (1), 7-30. Retrieved April 15, 2012 from http://revistas.fee.tche.br/index.php/ensaios/article/view/2401.
Hollensen, S. (2004). Global marketing. 3. ed. Harlow: Prentice Hall. Hopkins, M. (2005). Measurement of corporate social responsibility. International Journal of Management and Decision Making, 6(3), 213 231. http://dx.doi.org/10.1504/ijmdm.2005.006549

Hopkins, M. (2009). 8 Reasons Sustainability will change management. MIT Sloan Management Review, 27, 27-31. http://dx.doi. org/10.1016/b978-0-7506-7968-8.00003-x

Instituto Brasileiro de Geografia e Estatística - IBGE (2012). Retrieved April 23, 2012 from http://www.ibge.gov.br/home/presidencia/noticias/noticia_visualiza.php?id_noticia $=1703 \& i d$ _pagina $=1$.

Jamali, D. (2010). The CSR of MNC Subsidiaries in Developing Countries: Global, Local, Substantive or Diluted? Journal of Business Ethics, 93, 181-200. http://dx.doi.org/10.1007/s10551-010-0560-8

Konrad, A., Steurer, R., Langer, M., \& Martinuzzi, A. (2006). Empirical Findings on Business-Society Relations in Europe, Journal of Business Ethics, 63, 89-105. http://dx.doi.org/10.1007/s10551-005-7055-Z

Kotabe, M., \& Helsen, K. (2000). Administração de marketing global. São Paulo: Atlas.

Levine, M. (2008). China's CSR Expectations Mature. China Business Review. Retrieved February 05, 2013 from http://www.chinabusinessreview.com/public/0811/.

Maehler, A. (2011). Transferência de conhecimento em multinacionais: uma análise multidimensional de casos de empresas brasileiras no mercado português. (Doctoral dissertation). Federal University of Rio Grande do Sul, Porto Alegre, Rio Grande do Sul, Brazil. Retrieved April 10, 2012, from http://www.lume.ufrgs.br/handle/10183/36722.

Málovics, G., Kanó, I., Imreh, S. (2011). Companies, Stakeholders and Corporate Sustainability - Empirical Insights from Hungary. In: Environmental Management Accounting and Supply Chain Management, 27, 131-150. http://dx.doi.org/10.1007/978-94-007-1390-1_6

Maon, F., Lindgreen, A., Swaen, V. (2010). Organizational Stages and Cultural Phases: A Critical Review and a Consolidative Model of Corporate Social Responsibility Development. International Journal of Management Reviews, 12, 20-38. http://dx.doi.org/10.1111/j.14682370.2009.00278.x

Maon, F., Swaen, V. (2009). Shaping the Processual View of CSR: A Multipartite Sensemaking-Sensegiving Conceptualization. Procedings of Academy of Management Conference, 7-11, Chicago, Illinois, U.S.A.

Munasinghe, M. (2007). Sustainomics and sustainable development. Retrieved April, 10, 2012 from http://www.eoearth.org/view/article/156371 Myllyvainio, S., Virkkala, N. (2006). Corporate Social Responsibility: a concept under translation in China. Dept. of Business, Economics, Statistics and Informatics. Orebro University, Suécia. 
Nakos, G., Brouthers, K. D. (2002). Entry Mode Choice of SMEs in Central and Eastern Europe. Entrepreneurship Theory and Practice, 27, 47-63. http://dx.doi.org/10.1111/1540-8520.271003

Nelson, R.; Winter, S. (1982). Introduction. In: A evolutionary theory of economic change. Cambridge: Harvard. OECD. (2001). Sustainable development: critical issues. Paris: OECD Publications.

Parente, J. (2004). Responsabilidade social no varejo: conceitos, estratégias e casos no Brasil. São Paulo: Saraiva.

Pun, N. (2003). The moral economy of capital: transnational codes of conduct and labour rights in China. Chinese University conference Chinese Trade Unions and the Labour Movement in the Market Economy.

Santos, R. (2009) Relação entre Responsabilidade Social Corporativa e identidade de marca: uma abordagem ética. Universidade (UFU), Uberlândia, MG.

Shrivastava, P. (1995). Industrial / environmental crises and corporate social responsibility. The Journal of Socio-Economics, Netherlands, 24, 211-227, Springer. http://dx.doi.org/10.1016/1053-5357(95)90036-5

Steurer, R., Langer, M., Konrad, A., \& Martinuzzi, A. (2005). Corporations, Stakeholders and Sustainable Development I: A Theorical Exploration of Business-Society Relations, Journal of Business Ethics, 61, 263-281. http://dx.doi.org/10.1007/s10551-005-7054-0
Steurer, R., \& Konrad, A. (2009). Business-society relations in Central-Eastern and Western Europe: How those who lead in sustainability reporting bridge the gap in corporate (social) responsibility. Scandinavian Journal of Management, 25, 23-36. http://dx.doi. org/10.1016/j.scaman.2008.11.001

Tenório, F., \& Nascimento, F. (2006). Responsabilidade social empresarial: teoria e prática. 2. ed. Rio de Janeiro: Fundação Getúlio Vargas.

Vizeu, F., \& Matites, Q. (2013). Organizational Sacralization and Discursive Use of Corporate Mission Statements. Brazilian Administration Review, 10(2), 176-194. http://dx.doi.org/10.1590/s180776922013000200005

Wang, L., \& Juslin, H. (2009). The impact of Chinese Culture on Corporate Social Responsibility: The Harmony Approach. Journal of Business Ethics, 88(3), 433-451. http://dx.doi.org/10.1007/s10551009-0306-7

WCED - World Commission for the Environment and Development. (1987). Our Common Future, Oxford, Oxford University Press.

Yin, R. (2011). Qualitative Research from Start to Finish. New York: The Guilford Press.

Zadek, S. (2004). The path to corporate responsibility. Harvard Business Review, 82(12), 125-132.

Zhou, W. (2006). Will CSR Work in China? Leading Perspectives, CSR in the People's Republic of China. Beijing, Business for Social Responsibility, 5-7. 